\title{
Preparation The Battle of Manzikert in 1071 A.D. and Its Consequences to the Byzantine Empire
}

\author{
Kamaruzaman Yusoff, ${ }^{\mathrm{b}, *}$ Salah L-A Mohammed ${ }^{\mathrm{a},}$ Mansoureh Ebrahimi, $^{\mathrm{b}}$, Azlizan Mat Enh \\ ${ }^{a}$ School of History, Politics and Strategic Studies, National University of Malaysia (UKM) \\ ${ }^{b}$ Faculty of Islamic Civilization, Universiti Teknologi Malaysia (UTM) \\ *Corresponding author: Kamaruzaman Yusoff E-mail address:y.kamaruzaman@utm.my
}

Article history

Received: 2014-09-04

Received in revised form: 2014-10-27

Accepted: 2014-11-17

\begin{abstract}
This study aims to analyze the battle of Manzikert in 1071 A.D, and to examine its consequences on the Byzantine Empire. The methodology used in this article are primary sources namely manuscripts, historical records as well as secondary sources. The impact of Manzikert battle which occurred between the Byzantine Empire and the Seljuk State in 1071 A.D. indicates the powers and forces of the Byzantine Empire were destroyed economically and militarily. Actually, it is a turning point in the history of Christian-Muslim conflict. The Byzantine Empire started to set its eyes on the Catholic West to save it from dangers of the Islamic State and heathenish dangers represented by Pechenegs and Turkmen. However, it was not able anymore to defend itself after this battle. Hence, Manzikert battle increased Byzantine internal confusion and helped the Seljuk to interfere onto the Empire affairs. Finally, this study reveals that the Byzantine Empire was beginning to end from 1071 to 1204 A.D.
\end{abstract}

Keywords: Manzikert; Byzantine Empire; Seljuk State; Christian-Muslim conflict; Pechenegs; Turkmen 


\subsection{RELATIONSHIP BETWEEN THE SELJUK AND THE BYZANTINE EMPIRE}

The Byzantine Empire did not suffer from dangerous raids from the side of the Seljuk except in the era of the Emperor Constantine IX Monomachus (1042-1054 A.D.). In 1048 A.D, Ibrahim Yanal, the step-brother of Toghril Beg raided regions of the Byzantine Empire especially Trabzon city, Abkhaz and Erzurum city, thus, the Muslim Seljuk achieved exotic victories (Ibn al-Āthir, 1965-1967). In 1049 A.D., negotiations were initiated between the Byzantine emperor and the leader of the Seljuk, Toghril Beg, who released the king of Abkhaz in exchange for that Byzantines reconstruct a mosque in Constantinople. Then, prayers were performed in it and his name mentioned during the Friday sermon (Vryonis, 1971). In1051 A.D., Toghril Beg sent to the Emperor Constantine IX a messenger asking him to permit them to visit Egypt through the Levant. However, the Byzantine Empire refused the request of Toghrï Beg explaining to Toghrï Beg how close the relation between him and the Fātimid Caliph, alMustanșir Billah, and that he cannot permit to harm that caliph (al-Maqrīīi, 1973). The Byzantine Empire realized how strong and dangerous the Seljuk was especially after they conquered Baghdad. In 1055 A.D., the Byzantine empress, Theodora, received the messenger of the Seljuk Sultan Toghril Beg, and permitted him to give the speech for the Abbasid Caliph and the Seljuk sultan in Constantinople mosque (al-Maqrīzī, 1973). The Fātimid State could not launch any military action after its relations with the Byzantine Empire were spoiled due to being busy with the Seljuk attack of Iraq and the Levant, and the failure of al-Basāsīin as well as the tough and hard economical conditions (Charanis, 1953).

When Toghril Beg died in 1063 A.D., conflicts started for a short time among the Seljuk until Alp-Arslan, the nephew of Toghril Beg, conquered Rayy city in the late of 1063 A.D. So, in 1063 A.D. Alp-Arslan launched a huge crusade against Azerbaijan, then, he decided to fight the Byzantines and conquer them. After that, he headed for Kyrgyzstan country (al-Karj State) and attacked few of the Byzantine fortresses, then, he finished his victories by conquering Ani city, the capital of Armenia region. It was a very castellated city with a very strategic location. After the Seljuk seized this city, they undertook the Armenian highland which was the protective shield for the Byzantine Empire in the East due to its location and difficult roads (Vasiliev, 1952). After it was settled down for the Seljuk in Eastern and Southern regions, they set their eyes on the West, on the Levant where the powers of Fātimids as well as lands of the Byzantine Empire (Ibn Al-Amorany, 1973). In 1071 A.D., Alp-Arslan headed for the Levant. His arrival to the Levant was very significant. This was expressed best by the jurisprudent Abu Jaffar Ibn al-Bukhary, the judge of Aleppo, when he talked to Sultan Alp-Arslan during his way to cross Euphrates River heading for Aleppo in 1071 A.D., saying "O our patron, I thank Allah for this blessing which is that this river never been crossed by any Turkish or slave, but you crossed it and you are a king." This saying appealed to the Sultan. Aleppo was given to the Seljuk Sultan when Alp-Arslan reached it in 1071 A.D. Then, Alp-Arslan decided to give Aleppo freedom to a state (Ibn al-Ādim, 1968, p. 20) under the power of its governor Mahmud Ibn Nasr al-Maradsí.

While Sultan Alp-Arslan was on his way to Damascus to cross through to Egypt, he knew that the Byzantine Emperor had crossed Armenia aiming to seize Khurasan. So, he left Egypt and went back to Constantinople (alMaqrīīi, 1973). When the Seljuk's raids got fiercer and stronger against the Byzantine Empire, the Emperor Romanus IV Diogenes (1067-1071 A.D.) tried to stop the Seljuk march and blocked outlets in front of them. However, the Seljuk had entered inside and got outside the Byzantine Empire through three outlets; the lacunas in the North of the Levant, and lacunas upper the island, and Armenia. So, Romanus IV set a plan aiming to block those three outlets in three stages. Then, he himself led three crusades against the Levant, upper al-Jazira and Armenia in the years from 1068 to 1071 A.D. The first crusade the Emperor Romanus IV launched was in 1068 A.D. against lands of Aleppo emirate in the Levant and al-Jazīra. Romanus IV succeeded in his first crusade over Mahmud Ibn Nasr al-Maradsí, the prince of Aleppo, and those Turkmen and Arabs who were with him. After the Byzantine Emperor Romanus IV seized some fortresses, he backed off to his countries when he heard about the attacks of Turkmen who deepened inside the Byzantine lands (Zakar, 1972). In 1069 A.D, the Byzantine Empire Romanus IV, came back at the head of his crusade to the Levant in which he reached Manbij (or Hierapolis) village in Aleppo, thus, he captivated many of its people. After ruining villages existing between lands of the Byzantine Empire and Manbij, he withdrew due to lack of provisions and the spread of death and epidemics (al-Isfahani, 1978). 


\subsection{THE BATTLE OF MANZIKERT IN 1071 A.D. AND ITS CONSEQUENCES TO THE BYZANTINE EMPIRE}

The battle took place between Ahlat city and Manzikert, in the North of Lake Van in Armenia, and this was on 6th August, 1071 A.D. Before the battle, the Seljuk Sultan Alp-Arslan encouraged his soldiers saying, "I lose myself for Allah, so it is either happiness with martyrdom or victory" (Ibn al-Ādim, 1968). Troops of Alp-Arslan were of marksmen while the Byzantine troops were of knights with infantry. Ibn al-Ādim described that the Byzantine emperor inveighed with his army and Muslims rushed among them, "then, Muslims canalized the Byzantines till the ambush became behind them. Then, the ambush got out behind their back and they saw Muslims in front of them. Then, the Muslims broke the Romans, and the emperor was captivated and Muslims captivated his soldiers and zillions of loots and captives" (Ibn al-Ādim, 1968). Eventually, Muslims triumphed decisively and exotically and the Byzantine army was destroyed under the leadership of Romanus IV who was fallen a captive at the hands of the Muslim Seljuk Sultan (Vryonis, 1971).

No doubt, since the Byzantine army that faced its Seljuk counterpart consisted of mercenaries of Russians, Khazars, the Ghuzz, Turkmen, Pechenegs, Franks, and others; it lacked harmonization, good training and good organization. Besides they could not withhold the quick resistance of Seljuk knights and their rapid sudden attacks. Also, when the war broke out, the knights from the Ghuzz and Pechenegs betrayed the Byzantines by giving tribal loyalty to the Seljuk with whom they shared blood relationship. (Vasiliev, 1952). Besides, crowds of the Armenian soldiers got out of the battlefield due to their scorn to Byzantines resulting from doctrine disputes. The most important factors of their defeat is that the leader Andronicus Ducas escaped from the battlefield. This leader was the brother of the Emperor Constantine X Ducas (1059-1067 A.D). Andronicus wanted to ensure the future of his family after the Emperor Romanus IV dismissed his father out of his tasks, so he spread the rumours that the emperor was defeated. Then, he withdrew from the battlefield with his troops. All this, in turn, led to chaos and turbulences in the whole Byzantine army (Vryonis, 1967). The Byzantine army was moving very slowly, while the Seljuk army on the contrary, was very fast. According to Ibn Al-Ādim, that Sultan Alp-Arslan set a thorough scheme when he divided some of the army legions into groups of ambushes which hid behind the hills surrounding the battlefield. They assaulted the Byzantine army in the suitable time, thus, they had a very important role in taking it apart (Ibn al-Ādim, 1968).The captive Emperor Romanus IV, held a peace treaty with the Seljuk Sultan, AlpArslan. Based on which Alp-Arslan released him on one condition, he paid a huge ransom in addition to an annual tribute and gave Antioch, Edessa and Manbij to Muslims. He also promised to release the Seljuks captives and give military aids to the Seljuk when they were asked. Then, the Seljuk Sultan gave him 10,000 denarius, and sent with him a group of guards (Yousif, 1981). Defeating the Byzantines near Manzikert is considered a turning point in the Islamic history and the Byzantines as for the first time a Byzantine emperor fell captive at the hands of the Muslims. Manzikert battle also decided the future of Asia Minor as the Seljuk succeeded to conquer and deepen into it. They paved the way to the beginning of the fall and decline of the Byzantine Empire. The Byzantine Empire could not stand against the Seljuk expansion in Asia Minor. These regions, especially Armenia and Cappadocia, were very important to the Byzantine Empire because they always provided the Empire with many dynasties and several clever war and politics men (Frazee, 1976). The Byzantine Empire's loss of states of the East of Asia Minor, Armenia and Cappadocia in which the Seljuk settled down was an evidence and a proof that the Empire was about to die or at the least the beginning of its life end. According to Vryonis, when the Byzantine Empire lost its rich states in Asia Minor, "Constantinople became a head without the body which supports it" (Vryonis, 1967).

Nicetas Choniates stated that the Christian inhabitants of Asia Minor preferred the government of Seljuk to the Byzantine emperor. There were many followers like Paulicians and others who suffered from the Byzantine Empire's persecution. Also, the differentiation of races and languages in Asia Minor had its own impact on weakening the resistance against the Seljuk. Although the Greek was the language of most of inhabitants of cities in the beginning of Christianity's spread, it spread slowly in agricultural regions as farmers quite got stuck to their Asian accents till the Seljuk conquest (Choniates, 1912). Furthermore, Claude Cahen believed that Manzikert incident was an important phase within the long phases of Turkish deepening in Asia Minor (Cahen, 1938). Before 1071 A.D., the Turkish tribes were moving from Persia westerly, and the Turkish were sometimes used as mercenaries. However, after 1071 A.D., between 1071 A.D. and 1087 A.D., the Byzantine Empire resistance was ended and there were established Turkmen states under the leadership of Turkish leaders in different directions of Asia Minor and the Levant. These states got weakened due to the conflicts and competition that occurred among them. Finally the Turkish were united in Asia Minor under the Seljuk State with Konya as its capital. Moreover, the Seljuk deepening into Asia Minor was not similar to the usual pattern of attacks by a strong army. On the contrary, it started with stable deepening by tribes in the beginning before being followed by the attack by the strong military

Page $\mid 3$ 
forces (Cahen, 1938). Manzikert battles witnessed many important consequences that had great impact on the future of the Byzantine Empire, the Islamic world as well as the European West. This war proved that the Byzantine Empire was no longer the protective of the Western Christian World and the protective of Europe from the Islamic invasion. Thus, the West had to face the new situation, even it was said the inception of the Christians Wars was the war of Manzikert. Besides, William of Tyre (1947), the historian of the Christian Wars said that "this beating was one of the most important factors that served the Christian movement."

As a result, the ally between the Fâțimid and Byzantines was ended after the Byzantine Empire was obliged to hold a truce with the Seljuk. However Alp-Arslan did not exploit his victory and did not consider it a battle he fought and triumphed or on which he won some regional gaining. Thus, he did not try to seize the rest of Asia Minor, this battle was followed by radical changes in Asia Minor (Grousaet, 1947). Due to the battle, the Byzantine resistance collapsed and the Turkish quickly and suddenly spread in Asia Minor. This in turn led to changing the future of racial bloods in the region. Some historians referred this to the huge numbers of region inhabitants embraced Islam. The Byzantine administration was removed totally from Armenia and Cappadocia after their people abandoned them. Although these cities were given to the Seljuk, even asking the Seljuk for protection, the Seljuk left them to govern their own countries by themselves. Besides, the defense system used by the princes collapsed. Then the farmers soldiers got involved with Muslims and had good relations with them. At last, the Byzantine borders system was destroyed especially after the defeat. The Byzantine Empire was obliged to let go the mercenaries' soldiers in Armenia and Edessa and tried asking the native inhabitants for help. This led to the rise of hatred to the Byzantine Empire in these areas. The Seljuk's seizure of most of Armenian states led the Empire to lose an important human resource for its army as Armenians formed main and major brigades in the Byzantine army.

When the inhabitants of Constantinople heard about the battle of Manzikert and captivation of the Emperor Romanus IV Diogenes, Michael VII Parapinaces (1071-1078 A.D.) was assigned as a new emperor. Michael VII was a student of Bsellos, thus, he was fond of literature, scientific argument and writing prose without paying attention to the military activity at the time when the Empire was in a bad need for a strong military leader who can stand against the Seljuk (Vasiliev, 1952). When Romanus IV came back, he faced a fierce resistance in Constantinople and his eyes were obliterated, then, he soon died of his injures in 1072 A.D. The Emperor Michael VII and his consultants had hopes to fight the Seljuk again and regain the position of the Byzantine Empire in Asia Minor; however, this mission was far-fetched. Also, they had faith to achieve that by the help of Latin Europeans in the West. Thus, they went asking Robert Guiscard, the leader of Normans, for help. In 1071 A.D., Robert Guiscard had finished seizing the Byzantine possession in the South of Italy when he seized Bari city. This, in turn, made him the master of the South of Italy. Besides, the fall of Bari was evidence on the end of the Byzantine sovereign in the South of Italy. From this position in Puglia, Robert Guiscard was able to achieve quick victories by invading the rest of small regions that belonged to the Byzantine Empire inside Italy and these victories made it easy for him to restore Sicily from Muslims. Then, Guiscard became the duke of Puglia. He soon considered himself a successor of the Byzantine emperors (Vryonis, 1971).

Finally, the Emperor Michael VII found nothing except to hold an agreement with the Seljuk Sultan Sulaymān Ibn Qutalmïsh who became the leader of the Seljuk in Asia Minor. His father was the cousin of Toghril Beg. The Byzantine Empire admitted in this agreement the rights of the Seljuk to govern regions they took from the Byzantine Empire in Asia Minor. Then, Sulaymān seized the middle part of Asia Minor and established the Sultanate of Rûm. Its capital, Konya city (Iconium) was the richest and most beautiful Byzantine cities. From this important location in Asia Minor the Seljuk sultanate expanded till it reached the coasts of the Black Sea in the North and the coast of Mediterranean sea in the South. Then, this Sultanate became a very dangerous rival to the Byzantine Empire. Besides, the Seljuk pursued moving and expanding towards the west and the Byzantine Empire had no ability to stand this Seljuk expansion in Asia Minor (Vasiliev, 1952).

Accordingly, the Emperor Michael VII failed to solve the problem of the Byzantine Empire at the time when the internal tumults and turbulences and revolutions broke out (Ševčenko, 1961). Finally, Michael VII was deposed in 1078 A.D. and was forced to enter the monastery. Then, Nicephorus III Botaneiates (1078-1081 A.D.) became the emperor. He was a leader of lacunas in Asia Minor. Then, he entered the capital so the patriarch crowned him. As a new emperor then, Nicephorus III governed the Empire for three years; however, because he was old and weakbuilt, he could not run the Empire and solve its internal and external problems. A huge number of manor owners did not admit him as the emperor. Besides, there were a number of those who claimed that they were worthier of being emperor than him, appeared in different regions of the Empire. The triumph of the military aristocracy in the Byzantine Empire was when Alexius I, the most able military leader, became the emperor in 1081 A.D. He was an expert soldier and a clever politician who found the Byzantine Empire waned into small states. If the Byzantine 
Empire lasted for three centuries and a half, that was thanks to Emperor Alexius I (Vryonis, 1967). In confronting dangers which threatened the Empire, that came from the side of Normans, Pechenegs, and the Seljuk, Alexius I seized some of the Church possessions which were not exploited well and were neglected in order to finance the war (Ehrenkreutz, 1982). This led to frequent tension between him and the Church. However, Alexius I soon changed his policy and sometimes he handed possessions of the Church to some secular men for the purpose of investing them (Hussey, 1955).

Pronoia system (Ostrogorsky, 1952) prevailed in that era. These gifts were granted since the mid of the 10th century A.D. even without doing the military obligations which appeared for the first time in the era of Alexius I before 1119 A.D. The Pronoia owner gathered financial resources including taxes and fees from his farmer's tenants. Then, he served in the army with his military brigade. The number of his soldiers depended on the acreage and value of his Pronoia which was in general gifted forever and cannot be converted from one person to another (Ostrogorsky, 1952). Alexius I paid attention initially to the external policy and defending the Empire whether through diplomacy or war. In April 1081 A.D., the Emperor Alexius I, started to negotiate with the Seljuk in Asia Minor, and he admitted what they occupied in Asia Minor. He was hoping to stop their advance in order to free himself for Normans (Hussey, 1955). For the attitude of Alexius I towards Pechenegs and the Seljuk, they invaded the borders of the Byzantine Empire till a degree to which Anna Comnena (1967) sighed that the borders of the Byzantine Empire became Basifor near the East and Adrianople in the West. She added that her father, Alexius I started to fight the Berbers who surrounded the Empire at both sides. No doubt, Anna was referring to the Seljuk in the East and Pechenegs in the North. Ibn al-Ādim, mentioned that Suleiman Ibn Qutalmïsh exploited the weakness of the Byzantine Empire to occupy Antioch and few other locations of its manors, thus, Suleiman had from Nicaea to Tripoli. Besides, he had the lacunas of the Levant (Ibn al-Ādim, 1968). Alexius I had nothing to do to stand against the Seljuk as the conquests of Pechenegs were very severe and fierce in the North. In the end of the 11th century A.D., Alexius I was defeated badly by the Pechenegs at Silistria city. However, the Pechenegs did not benefit completely from their victory. In 1090-1091 A.D., Pechenegs allied with the governor of İzmir city (Smyrna) and attacked Constantinople by land and sea. Eventually, Alexius I was able to use the known diplomatic policy of the Byzantine Empire by rousing a Barbarian sect against the other. With the help of Turkmen and Russians he defeated Pechenegs on the 29th April 1091 A.D., at the Mountain of Revolution Peak. However, his plans went down the drain when the first Crusade approached from Constantinople.

\subsection{CONCLUSION}

To conclude, the Seljuks were more dangerous than many other enemies whom the Byzantine Empire defeated in its previous history. Gradually, the Empire became weaker, and all of those dangers which rose in the 11th century A.D. harmed the Byzantine Empire in the last period of its lifetime (1071 to 1204 A.D.). On the contrary, the Seljuk State was able to make many victories over the Byzantine Empire. For example, in 1063 A.D, the Seljuk State conquered Ani city, the capital of Armenia. Afterwards, they took over the highland of Armenia which was the protective shield for the Byzantine Empire in the East as well as most of Asia Minor regions which provided the Byzantine Empire with armies and livings. Besides, the battle paved the way to the rise of the state of Seljuk Rûmin with Konya as its capital. Then, they started to expand northerly, not only in the directions of the Dead Sea, but also southerly in the directions of the Mediterranean Sea.

\section{References}

Anna Comnena. (1967). The Alexiad of the Princess Anna Comnena. (A. S. E. Dawes, Trans.). London: n.p.

Brice, W. C. (1956). “The Turkish colonization of Anatolia”. Bulletin of the John Ryland's Library, 38 (1), 18-44.

Cahen, C. (1938). Les Grandes Lignes de I'history de la pénétration Turque en Anatolieet en Syrie pendant la seconde moitié du Xe siécle. Brussels: Actes du XXe Congrés International des Orientalistes.

Charanis, P. (1953). Economic factors in the decline of the Byzantine Empire. The Journal of Economic History, 13(4), 412-424. doi: 10.2307/2114773.

Choniates, N. (1912). The sack of Constantinople 1204 (Vol. 3). ( D. C. Munro, Trans.). Philadelphia: University of Pennsylvania Press. 
Ehrenkreutz, A. S. (1982). The dreadful day: The Battle of Manzikert 1071 [Review of the book by Alfred Friendly]. Middle East Journal, 36(4), 600-601. doi: 10.2307/4326483.

Frazee, C.A. (1976). The Christian Church in Cilician Armenia: Its relations with Rome and Constantinople to 1198. Church History, 45(2), 166-184. doi: 10.2307/3163715.

Grousaet. (1947). Histoira de Armenia. Paris: n.p.

Holt, P. M., Lambton, A., \& Lewis, B. (1970). The Cambridge history of Islam: The central Islamic lands from preIslamic times to the First World War (Vol. 1A). Cambridge: University Press.

Hussey, J. M. (1955). The Byzantine world (3rd ed.). London: n.p.

Ibn al-Ādim. (1968). Zubdat al-halab fi tārīkh Halab (Vol. 1). Sami al-Dahan (Ed.). Dimashq: Maṭba'ah alMuqtabas.

Ibn al-Āthīr. (1965-1967). Al-kāmil fì al-tārīkh. Bayrūt: Dār Șādir.

Ibn Al-Amorany. (1973). Al-Anba' fi tārīkh Al-Khulafā'. Qasim al-Samarrai (Ed.). Leiden: n.p.

Al-Isfahānī. (1978). Tārikh Dawlah al-Saljuk. Bayrūt. Manshūrat al-Maktabah al-'Așriyyah.

Al-Maqrīzī. (1973). Ette'aaz al-honafa be Akhbaar al-A'emma Al-Fatimiyyin Al-Khulafa. Mohammed Halimi Mohammed (ed.), Vol. 1. Al-Qāhirah: Dār al-Kutub.

Ostrogorsky, G. (1952). Surla pronia à propos de l'article de M. Lascaris. Byzantion. 22, 161-163.

Ostrogorsky, G. (1956). History of the Byzantine State. (J, Hussey, Trans.) Oxford: n.p.

Ševčenko, I. (1961). The decline of Byzantium seen through the eyes of its intellectuals. Dumbarton Oaks Papers, 15, 167-186. doi: 10.2307/1291179.

Vasiliev, A. A. (1952). A history of the Byzantine Empire 324-1453 C.E. (Vol. 1). Wisconsin: n.p.

Vryonis, S. J. (1967). Byzantium and Europe. London: Harcourt, Brace and Co.

Vryonis, S. J. (1971). The decline of medieval Hellenism in Asia Minor and the process of Islamization from eleventh through the fifteenth century. California: University of California Press.

William, of Tyre. (1947). A History of deeds done beyond the sea (Vol. 2). (A. C. Krey \& E. A. Babcock, Trans.). New York: n.p.

Yousif, J. N. (1981). Al-'Arab wa al-Rūm wa al-Latin fi al-ḥarb al-ṣalibiyyah. Bayrūt: Dār al-Naḥ̣ah al'Arabiyyah.

Zakar, S. (1972). Madkhal ilā tarikh al-hurūb al-ṣalibiyyah. Lubnān: Mu'assasah al-Risālah. 